TITLE:

\title{
Adipose tissue formation in collagen scaffolds with different biodegradabilities.
}

$\operatorname{AUTHOR}(S)$ :

Kimura, Yu; Inamoto, Takashi; Tabata, Yasuhiko

\section{CITATION:}

Kimura, Yu ...[et al]. Adipose tissue formation in collagen scaffolds with different

biodegradabilities.. Journal of biomaterials science. Polymer edition 2010, 21(4): 463-476

ISSUE DATE:

2010-03-01

URL:

http://hdl.handle.net/2433/139429

RIGHT:

(C) 2010 VSP, an imprint of Brill 


\title{
Adipose Tissue Formation in Collagen Scaffolds with Different Biodegradabilities
}

\author{
Yu Kimura ${ }^{\mathrm{a}}$, Takashi Inamoto ${ }^{\mathrm{b}}$ and Yasuhiko Tabata ${ }^{\mathrm{a}, *}$ \\ ${ }^{a}$ Department of Biomaterials, Field of Tissue Engineering, Institute for Frontier Medical Sciences, \\ Kyoto University, Kyoto, Japan \\ ${ }^{\mathrm{b}}$ Department of Breast Surgery, Kitano Hospital, The Tazuke Kofukai Medical Research Institute, \\ Osaka, Japan
}

Received 25 November 2008; accepted 19 February 2009

\begin{abstract}
In vivo adipose tissue regeneration by preadipocytes was evaluated by combining them with collagen sponges with different biodegradabilities and gelatin microspheres incorporating basic fibroblast growth factor (bFGF) for the controlled release. The collagen sponge biodegradability was regulated from 1-4 weeks by changing the cross-linking conditions in collagen sponge preparation. The time profile of bFGF release was controlled from 1-5 weeks by the biodegradability of gelatin microspheres used. The collagen sponges combined with human preadipocytes and gelatin microspheres incorporating bFGF were implanted into the back subcutis of nude mice to evaluate the adipose tissue regeneration. The regeneration of adipose tissue was observed in every collagen sponge. The area of regenerated adipose tissue was maximal in the collagen sponge with a degradation time of 2 weeks. No influence of the time profile of bFGF release on the area of regenerated adipose tissue was detected.

(c) Koninklijke Brill NV, Leiden, 2010
\end{abstract}

\section{Keywords}

Biodegradability, collagen, scaffold, controlled release, bFGF, adipogenesis, gelatin

\section{Introduction}

In the reconstruction surgery of adipose tissues for the treatments of breast or subcutaneous adipose tissue defects, the grafting of autologous semi-liquid free fat tissue of a few millimeters in size has been clinically performed [1, 2]. However, this therapy often meets some problems, such as the absorption and fibrosis of tissues grafted [3-5]. As one trial to tackle the problems, it is important to artificially induce de novo formation of adipose tissue at the defect site, which will be a promising therapeutic substitute for the tissue graft.

\footnotetext{
* To whom correspondence should be addressed. E-mail: yasuhiko@frontier.kyoto-u.ac.jp 
Recently, tissue engineering has been being noticed as a newly emerging biomedical technology to repair or regenerate body defects by combining stem or precursor cells with their scaffolds and growth factors $[6,7]$. There are two possible strategies based on tissue engineering to induce de novo adipogenesis. The first strategy is to make use of cells with high potentials for proliferation and differentiation to achieve cells-induced regeneration of adipose tissues. The cells are transplanted into a body site where de novo formation of adipose tissue is expected. For example, it is reported that a cell line of preadipocytes induced the formation of adipose tissue at the subcutaneous site injected in nude mice [8]. This strategy is practically applicable for regeneration of fat tissues, and some trials have been reported [9-12]. Patrick et al. have succeeded in the formation of adipose tissues in the rat subcutis by use of porous scaffold of poly(lactic-co-glycolic acid) pre-seeded with preadipocytes autologously isolated [10,13]. Adipose tissue engineering using a collagen scaffold combined with human preadipocytes has also been reported [11, 14]. We have demonstrated adipose tissue regeneration by the subcutaneous implantation of human preadipocytes combined with a collagen sponge and gelatin microspheres incorporating bFGF which can achieve the controlled release. The controlled release technology with the microspheres enabled bFGF to enhance the biological activities of preadipocytes proliferation and neovascularization into the scaffold [15], resulting in promoted cells-induced adipose tissue regeneration.

The second way is to induce the in vivo formation of adipose tissues by making use of the potentials of precursor or stem cells, like preadipocytes, originally present in the body. If it is possible to provide the cells with a local environment suitable for their proliferation and differentiation, de novo formation of adipose tissue will be expected without exogenous transplantation of cells necessary for adipogenesis. De novo adipogenesis in the mouse subcutis could be induced by the injection of mixed bFGF and an extract of basement membrane of murine tumor cell line (Matrigel ${ }^{\circledR}$ ) [16]. Mixing with the Matrige ${ }^{\circledR}$ promoted the angiogenic activity of bFGF [17], which is essential for the generation and maintenance of adipose tissue. We have succeeded in the controlled release of bFGF from gelatin hydrogels [18] and enhanced the angiogenic effect in vivo [19]. Following the subcutaneous implantation of Matrigel ${ }^{\circledR}$ combined with the hydrogel for bFGF release into the mouse back, significantly higher de novo adipogenesis at the implanted site was observed than the implantation of mixed Matrigel ${ }^{\circledR}$ and free bFGF [20, 21]. In addition, we reported that the implantation of collagen sponge alone into a natural adipose tissue achieved successful the regeneration of adipose tissues in the collagen sponge [22]. It is highly conceivable that precursor cells are migrated into the collagen sponge of suitable scaffold from the surrounding tissues, resulting in in situ regeneration of adipose tissue. To this end, biomaterial design and preparation of scaffolds to promote cell migration and proliferation or growth factor delivery have been extensively tried $[6,23]$. The idea is that biomaterials for cell scaffolds, space making membranes, and growth factors delivery give cells a local environment necessary for cell-induced tissue regeneration. 
This study is undertaken to obtain fundamental information about effect of the biodegradability of collagen sponge scaffolds and the time profile of bFGF release on adipose tissue regeneration. Although the in vivo degradability of scaffolds has an important influence on successful tissue regeneration and replacement [24], little has been reported about this issue. In addition, the time profile of bFGF release may affect adipose tissue regeneration. In the present study, collagen sponges with different rates of biodegradability were prepared by changing the cross-linking conditions in sponge preparation, while the biodegradation profile of gelatin microspheres was changed to alter the time profile of bFGF release. Following the subcutaneous implantations of collagen sponges combined with human preadipocytes and the gelatin microspheres incorporating bFGF into the back subcutis of nude mice, the histological area of adipose tissue newly formed was evaluated in terms of scaffolds biodegradability and time profile of bFGF release.

\section{Materials and Methods}

\subsection{Materials}

An aqueous solution of human recombinant bFGF with an isoelectric point (IEP) of $9.6(10 \mathrm{mg} / \mathrm{ml})$ was kindly supplied by Kaken Pharmaceutical (Tokyo, Japan). Collagen solution (pH 3.0, $0.3 \mathrm{wt} \%$ ) was kindly supplied by Nitta Gelatin (Osaka, Japan). A gelatin sample with an IEP of 5.0 (Nitta Gelatin) was prepared through an alkaline process of type I collagen obtained from the bovine bone. Glutaraldehyde (GA), glycine and other chemicals were purchased from Wako (Osaka, Japan) and used without further purification.

\subsection{Preparation of Collagen Sponges}

Type I bovine collagen solution $(10 \mathrm{ml})$ was poured into an aluminum mold $\left(6 \times 6 \mathrm{~cm}^{2}\right)$ and frozen at $-20^{\circ} \mathrm{C}$. Then, the samples were freeze-dried to obtain porous sponges. The freeze-dried sponge was placed in a vacuum oven for dehydrothermal cross-linking of collagen $\left(105^{\circ} \mathrm{C}, 0.01\right.$ Torr, $\left.24 \mathrm{~h}\right)$, and next immersed to various concentrations of glutaraldehyde solution for various time periods (Table 1) for chemical cross-linking at $4^{\circ} \mathrm{C}$. Then, the cross-linked sponges were immersed in $100 \mathrm{mM}$ glycine aqueous solution to block the residual aldehyde groups, and washed with double distilled water (DDW) thoroughly. The resultant sponges were freeze-dried again and sterilized by ethyleneoxide.

\subsection{Preparation of Gelatin Microspheres Incorporating $b F G F$}

Gelatin microspheres were prepared through the gelation of gelatin aqueous solution in an emulsion state, followed by the chemical cross-linking with glutaraldehyde solution in the dispersion state as reported previously [25]. Briefly, $10 \mathrm{ml}$ gelatin aqueous solution preheated at $45^{\circ} \mathrm{C}$ was added drop-wise to $375 \mathrm{ml}$ olive oil under stirring at $420 \mathrm{rpm}$ and $45^{\circ} \mathrm{C}$ to obtain a w/o emulsion. Stirring was continued at $4^{\circ} \mathrm{C}$ for $1 \mathrm{~h}$ to allow gelatin for gelation. After the addition of $100 \mathrm{ml}$ acetone 
Table 1.

Preparation of cross-linked collagen sponges

\begin{tabular}{llll}
\hline Code & Dehydrothermal cross-linking & GA $(\mathrm{wt} \%)$ & Reaction time (h) \\
\hline C1 & + & - & - \\
C2 & + & 0.02 & 3 \\
C3 & + & 0.02 & 24 \\
C4 & + & 0.2 & 3 \\
C5 & + & 0.2 & 24 \\
\hline
\end{tabular}

Table 2.

Preparation of cross-linked gelatin microspheres

\begin{tabular}{lll}
\hline Code & GA $(w t \%)$ & Reaction time $(\mathrm{h})$ \\
\hline G1 & 0.620 & 24 \\
G2 & 1.24 & 24 \\
G3 & 6.10 & 24 \\
\hline
\end{tabular}

to the reaction mixture, the resulting microspheres were collected by centrifugation (5000 rpm, $4^{\circ} \mathrm{C}, 5 \mathrm{~min}$ ) and washed 5 times with acetone by centrifugation.

The non-cross-linked and dried gelatin microspheres $(500 \mathrm{mg})$ were placed in $0.1 \mathrm{wt} \%$ of Tween-80 aqueous solution containing different concentrations of GA (Table $2,100 \mathrm{ml}$ ) and stirred at $4^{\circ} \mathrm{C}$ for $15 \mathrm{~h}$ to proceed their cross-linking. After collecting by centrifugation $\left(5000 \mathrm{rpm}, 4^{\circ} \mathrm{C}, 5 \mathrm{~min}\right)$, the microspheres were further agitated in $100 \mathrm{ml}$ of $100 \mathrm{mM}$ glycine aqueous solution at $37^{\circ} \mathrm{C}$ for $1 \mathrm{~h}$ to block the residual aldehyde groups of untreated $\mathrm{GA}$. The resulting microspheres were finally washed with DDW, centrifuged at $5000 \mathrm{rpm}$ for $5 \mathrm{~min}$, and freeze-dried.

The original bFGF solution was diluted with DDW to adjust the solution concentration to $50 \mu \mathrm{g} / \mathrm{ml}$. The aqueous solution of bFGF $(20 \mu \mathrm{l})$ was dropped onto $2 \mathrm{mg}$ freeze-dried gelatin microspheres, followed by leaving at $25^{\circ} \mathrm{C}$ for $3 \mathrm{~h}$ for impregnation of bFGF into the microspheres. The bFGF solution was completely absorbed into the microspheres through the impregnation process because the solution volume was much less than that theoretically required for the equilibrated swelling of microspheres. Our previous study indicated that the time periods of gelatin microspheres completely degraded in vivo were 1, 3 and 5 weeks for G1, G2 and G3 microspheres, respectively [26].

\subsection{Evaluation of Collagen Sponges Biodegradability}

All animal experiments were performed under permission from Animal Experiment Committee of Institute for Frontier Medical Sciences, Kyoto University and followed by the Guidelines for Animal Experiments of Institute for Frontier Medical Sciences, Kyoto University. 
The in vivo degradation profile of collagen sponges was evaluated by the method previously reported [27]. Briefly, $20 \mu \mathrm{l}$ of phosphate-buffered saline (PBS, pH 7.4) solution of $\left[{ }^{125} \mathrm{I}\right]$ Bolton-Hunter reagent (NEX120H, Perkin-Elmer, Waltham, MA, USA) was homogeneously dropped onto collagen sponges $\left(5 \times 5 \times 3 \mathrm{~mm}^{3}\right)$ for radiolabeling. After incubation of sponges at $4^{\circ} \mathrm{C}$ for $3 \mathrm{~h}$, the sponges were washed with DDW at $4{ }^{\circ} \mathrm{C}$ thoroughly, then implanted into the back subcutis of female ddY mice, 6 week-age (Shimizu Laboratory Supply, Kyoto, Japan). Remaining sponges and tissues around the implantation site were obtained at different time intervals and their radioactivity was counted by a gamma counter (ARC-360, Aloka, Tokyo, Japan) to evaluate the biodegradation profile of collagen sponges.

\subsection{Isolation and Culture of Human Preadipocytes}

Isolation and culture of human preadipocytes were performed by the method previously reported [15]. Briefly, human preadipocytes were primarily isolated from human adipose tissues that were obtained in the axillary lymph node dissection of breast cancer patients with informed consent at Kyoto University Hospital. The adipose tissue was washed with PBS to carefully remove blood cells, then minced, and digested with $520 \mathrm{U} / \mathrm{ml}$ collagenase (Nitta Gelatin) with $20 \mathrm{mg} / \mathrm{ml}$ bovine serum albumin (Nacalai Tesque, Kyoto, Japan) and a DMEM/F12 mixture (1:1, SigmaAldrich, St. Louis, MO, USA) in a water bath at $37^{\circ} \mathrm{C}$ for 30 min under shaking. The digested was suspended in Medium 199 containing $10 \mathrm{vol} \%$ fetal bovine serum (FBS), followed by centrifugation $\left(1000 \mathrm{rpm}, 4^{\circ} \mathrm{C}, 5 \mathrm{~min}\right)$ to remove the supernatant. After washed twice with the medium, the cells obtained were cultured in a cell-culture flask $\left(75 \mathrm{~cm}^{2}\right.$, Corning 430720,1000 cells $\left./ \mathrm{cm}^{2}\right)$ in the medium containing $0.1 \mu \mathrm{g} / \mathrm{ml} \mathrm{bFGF}$ at $37^{\circ} \mathrm{C}$ and $5 \% \mathrm{CO}_{2} / 95 \%$ air atmosphere pressure. The cells were expanded and subjected to the following in vivo experiments. The morphological feature of the cells was fibroblast-like. When the cells were cultured in the presence of $50 \mathrm{nM}$ insulin, $100 \mathrm{nM}$ dexamethasone, $10 \mu \mathrm{g} / \mathrm{ml}$ transferrin and $200 \mathrm{pM}$ triiodethyronine for 14 days, they accumulated fat droplets inside [15]. This suggests that the cells isolated had an inherent nature to differentiate into matured adipocytes.

\subsection{Cell Attachment Test for Collagen Sponges}

The cell compatibility of collagen sponges was evaluated by the initial cell attachment of human preadipocytes based on the previous study [28]. Briefly, $500 \mu \mathrm{l}$ of a cell suspension $\left(2 \times 10^{6}\right.$ cells $\left./ \mathrm{ml}\right)$ was poured in a polypropylene tube (2236012N, Iwaki Glass, Chiba, Japan). A collagen sponge (6 mm diameter, $3 \mathrm{~mm}$ thickness) was placed in the cell suspension, followed by agitation with an orbital shaker (Bellco Glass, Vineland, NJ, USA) at $300 \mathrm{rpm}$ for $6 \mathrm{~h}$. The cell-seeded collagen sponges were thoroughly washed with PBS to exclude non-adherent cells. The number of cells attached in collagen sponge was determined by the fluorometric quantification assay of cellular DNA [29]. Briefly, cell-seeded sponges were digested by the collagenase solution in a water bath at $37^{\circ} \mathrm{C}$ for 30 min under shak- 
ing. The cells prepared were washed with PBS twice and stored at $-20^{\circ} \mathrm{C}$ until assayed. After thawing, cells were lysed in $1 \mathrm{ml}$ of a buffer solution ( $\mathrm{pH} 7.4$ ) containing $0.2 \mathrm{mg} / \mathrm{ml}$ of sodium dodecyl sulfate and $30 \mathrm{mM}$ sodium citrate-buffered saline (SSC) with pipetting. The cell lysate $(100 \mu \mathrm{l})$ was mixed with $400 \mu \mathrm{l}$ of SSC buffer. After mixing with $500 \mu \mathrm{l}$ of a dye solution containing $30 \mathrm{mM} \mathrm{SSC}$ and $1 \mu \mathrm{g} / \mathrm{ml}$ Hoechst 33258 (Nacalai Tesque), the fluorescence intensity of the mixed solution was measured with a fluorescence spectrometer (F-2000, Hitachi, Tokyo, Japan) at excitation and emission wavelengths of 355 and $460 \mathrm{~nm}$, respectively. The percent cells attached was estimated from the calibration curve prepared by use of known initial number of cells.

\subsection{In Vivo Implantation}

bFGF aqueous solution $(20 \mu \mathrm{l}, 0.05 \mathrm{mg} / \mathrm{ml})$ was dropped onto $2 \mathrm{mg}$ of freeze-dried gelatin microspheres, followed by leaving at $25^{\circ} \mathrm{C}$ for $3 \mathrm{~h}$ to obtain gelatin microspheres incorporating bFGF. The microspheres were mixed with the suspension of human preadipocytes at a density of $1 \times 10^{5}$ cells $/ 50 \mu \mathrm{l}$ culture medium. The mixed suspension was dropped on the freeze-dried collagen sponge $(10 \times 10 \times$ $3 \mathrm{~mm}^{3}$ ), followed by incubation at $37^{\circ} \mathrm{C}$ for $3 \mathrm{~h}$ and $5 \% \mathrm{CO}_{2} / 95 \%$ air atmosphere pressure to obtain the collagen sponge combined with human preadipocytes and gelatin microspheres incorporating bFGF. The cell density and bFGF dose were selected as the optimal conditions based on the paper previously reported [15].

Under anesthesia, the collagen sponge incorporating human preadipocytes and gelatin microspheres incorporating bFGF was carefully implanted into the back subcutis of 6-weeks-old, female BALB/c nude mice, $1.5 \mathrm{~cm}$ apart from the tail root at the body center where is free of originally existing adipose tissue. Each experimental group was composed of 6 mice. Four weeks after implantation, the mice were killed by an overdose injection of anesthetic and the skin including the implanted site $\left(2 \times 2 \mathrm{~cm}^{2}\right)$ was carefully taken off for the subsequent examinations.

\subsection{Histological Analysis}

De novo formation of adipose tissues at the implanted site was assessed in terms of histological examination. The skin flap including implanted site was fixed with $10 \%$ neutralized formalin solution, embedded in paraffin and sectioned $(4 \mu \mathrm{m}$ in thickness) at the portion of implanted site as central as possible, followed by staining with hematoxylin and eosin (HE).

Microphotographs of 6 cross-sections from 6 different mice were taken at a similar magnification to evaluate the de novo formation of adipose tissue. The same area of interest ( 3 portions/cross-section, $0.8 \times 0.5 \mathrm{~mm}^{2}$ ) was randomly selected by blind assessors with blinding the experimental groups indication and the area occupied by matured adipocytes at the implanted site for every portion was measured to express as the area of adipose tissue. 


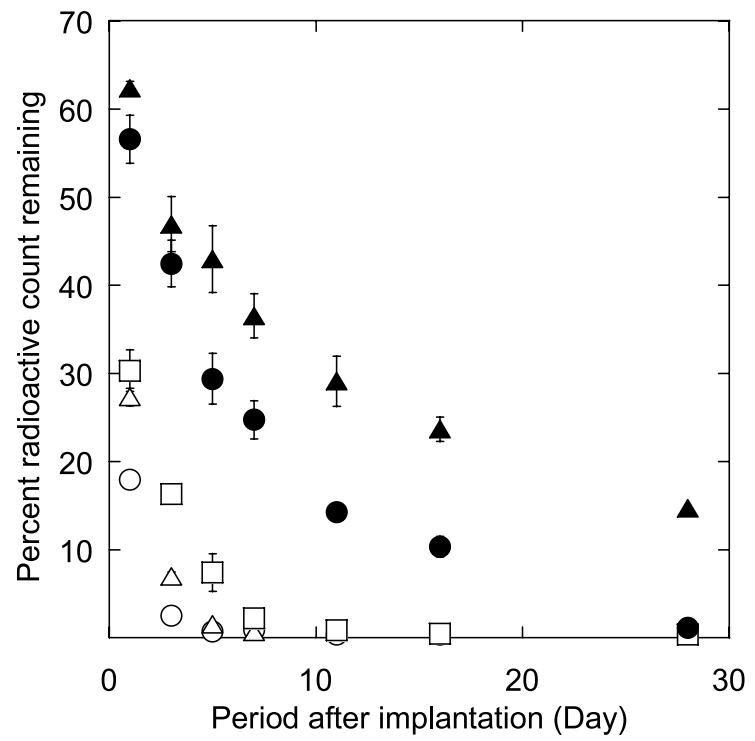

Figure 1. In vivo degradation profiles of collagen sponges after implantation into the back subcutis of mice: $(\bigcirc) \mathrm{C} 1,(\triangle) \mathrm{C} 2,(\square) \mathrm{C} 3,(\bullet) \mathrm{C} 4$ and $(\boldsymbol{\Delta}) \mathrm{C} 5$ sponges.

\subsection{Statistical Analysis}

All the data were analyzed by Fisher's LSD test for multiple comparisons and the statistical significance was accepted at $P<0.05$. Experimental results were expressed as the mean + standard deviation of the mean $(\mathrm{SD})$.

\section{Results}

Figure 1 shows the biodegradability of collagen sponges in mice subcutis. The collagen sponges were radiolabeled with the Bolton-Hunter reagent and their biodegradability was evaluated by counting the remaining radioactivity around the implanted site after subcutaneous implantation. In the case of $\mathrm{C} 1$ sponges without GA-cross-linking, the sponges disappeared three days after implantation. In contrast, GA-cross-linked sponges were remained in the body for longer time periods, and the remaining time of radioactivity around the implanted sites changed from 7 to 35 days. The degradation profile of collagen sponges could be controlled by changing GA concentration and cross-linking time. The higher GA concentration and the longer treatment time, the longer time period the collagen sponges remained.

Figure 2 shows the ratio of human preadipocytes attached into collagen sponges $6 \mathrm{~h}$ after orbital agitation with cell suspension. About $50 \%$ of the cells seeded was attached into any collagen sponge. There was no significant difference in the cell number ratio among all the groups. 


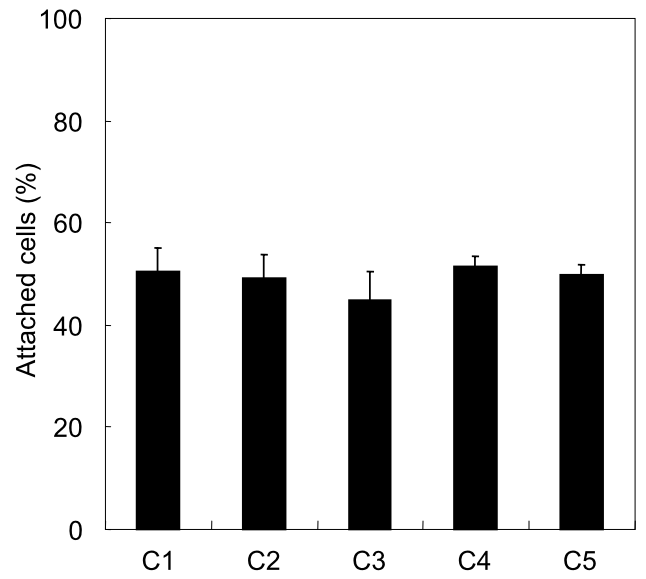

Figure 2. Number of cells attached to collagen sponges $6 \mathrm{~h}$ after agitation cell seeding.

Figure 3 shows the histological sections of C1-C5 collagen sponges combined with human preadipocytes and G2 gelatin microspheres incorporating bFGF into back subcutis of nude mice 4 weeks after implantation. Except for the C5 collagen sponge group, matured adipocytes, which are indicated as white circular cells in Fig. 3 and denoted 'F', were observed in every group at subcutaneous implanted site, although the number depended on the group. Eosin-stained ribbon-like matrices were observed at the implanted site of $\mathrm{C} 4$ and C5 collagen sponge implantation groups.

Figure 4 shows the area of adipose tissues determined from the histological image analysis 4 weeks after implantation of collagen sponges $\mathrm{C} 1-\mathrm{C} 5$ combined with human preadipocytes and G2 gelatin microspheres incorporating bFGF. The highest area of adipose tissues newly formed was observed for the collagen sponge with a biodegradability of 2 weeks. If the biodegradation period was shorter than 2 weeks, the cross-sectional area of adipose tissues newly formed was smaller. The area was also smaller for the sponge with longer biodegradation time periods.

Figure 5 shows the histological sections at the implanted site of C3 collagen sponges combined with human preadipocytes and gelatin microspheres G1-G3 incorporating bFGF. Matured adipocytes were observed in every group at subcutaneous implanted site. Figure 6 shows the area of adipose tissues determined from the histological image analysis 4 weeks after implantation C3 collagen sponges combined with human preadipocytes and gelatin microspheres G1-G3 incorporating bFGF. There was no significant difference in the cross-sectional area of adipose tissues newly formed among the G1-G3 groups.

\section{Discussion}

We have evaluated the effect of sponge scaffold biodegradation and bFGF release profiles on the de novo regeneration of adipose tissues. As a result, an optimal 

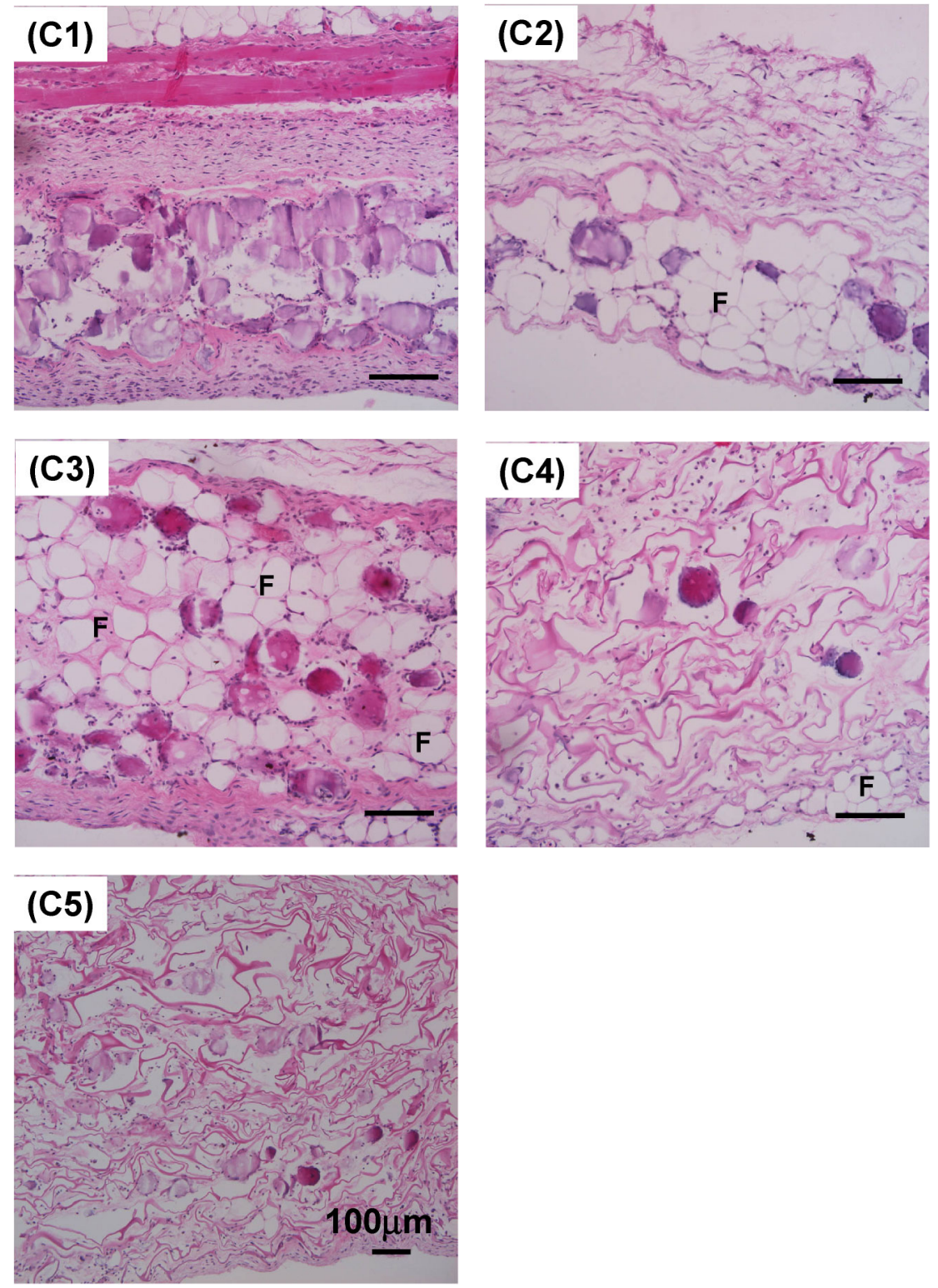

Figure 3. Histological cross-sections of $\mathrm{C} 1, \mathrm{C} 2, \mathrm{C} 3, \mathrm{C} 4, \mathrm{C} 5$ collagen sponges combined with human preadipocytes and G2 gelatin microspheres incorporating bFGF 4 weeks after implantation into the back subcutis of nude mice. F, matured adipocyte. This figure is published in colour in our online edition, which can be accessed via http://www.brill.nl/jbs

degradation time of scaffolds was found for preadipocyte-induced regeneration of adipose tissues. We have already reported that adipose tissue engineering was achieved by the implantation of collagen sponge with human preadipocytes and releasing system of bFGF. It is demonstrated that there was an optimal cell number 


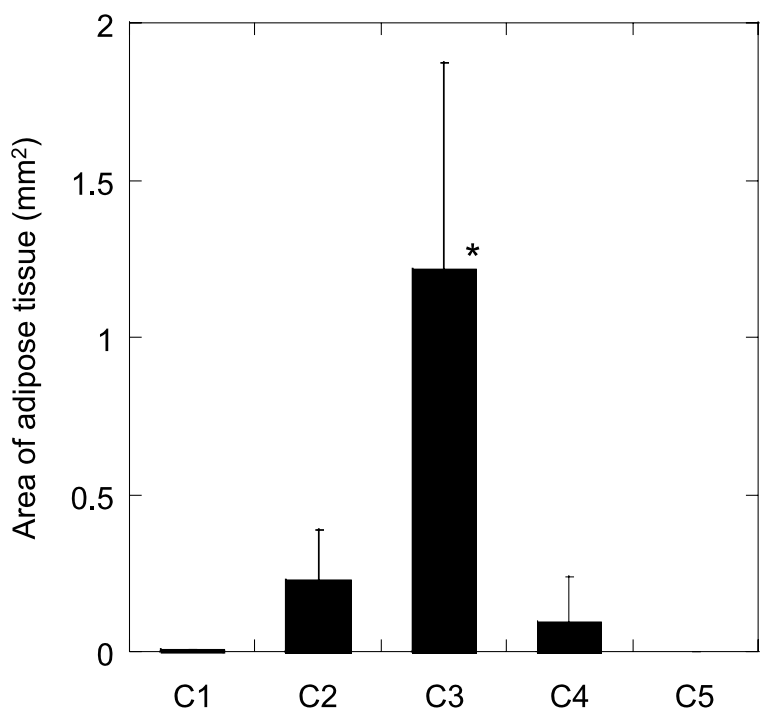

Figure 4. Area of adipose tissues newly formed 4 weeks after implantation of C1, C2, C3, C4 and C5 collagen sponges combined with human preadipocytes, and G2 gelatin microspheres incorporating bFGF into the back subcutis of nude mice.
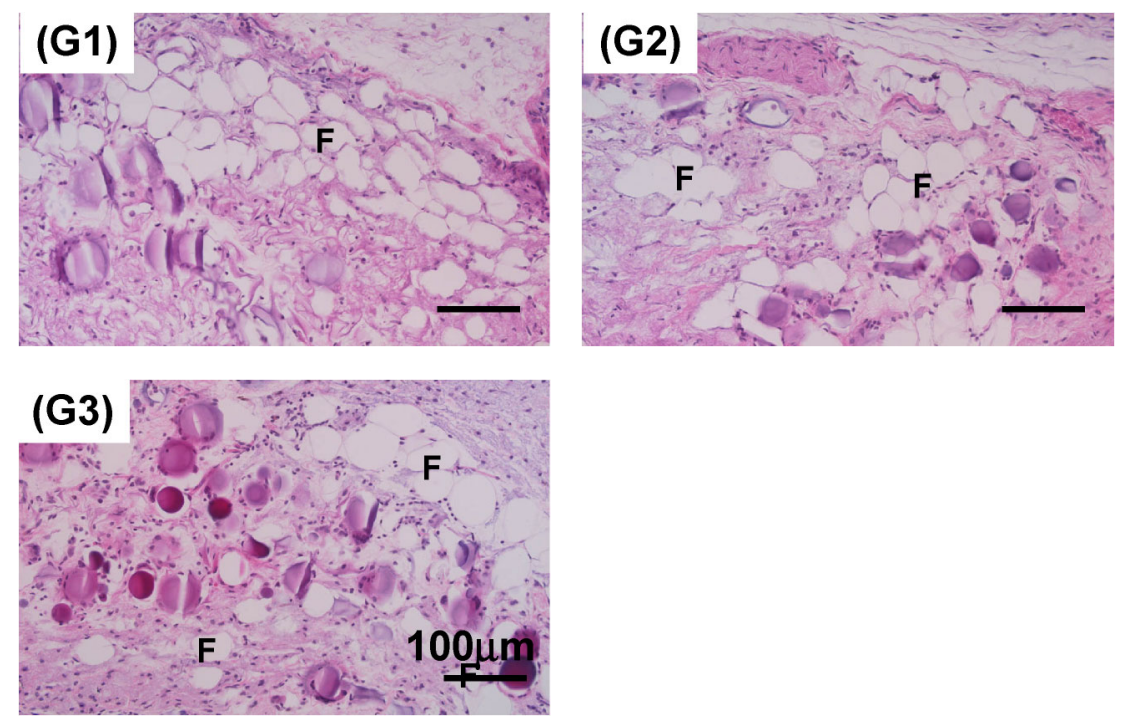

Figure 5. Histological cross-sections of $\mathrm{C} 3$ collagen sponges combined with human preadipocytes, and G1, G2 and G3 gelatin microspheres incorporating bFGF 4 weeks after implantation into the back subcutis of nude mice. F, matured adipocyte. This figure is published in colour in our online edition, which can be accessed via http://www.brill.nl/jbs

and bFGF dose for de novo adipose tissue regeneration [15]. In this study, based on the cell number and bFGF dose experimentally optimized by our previous paper, 


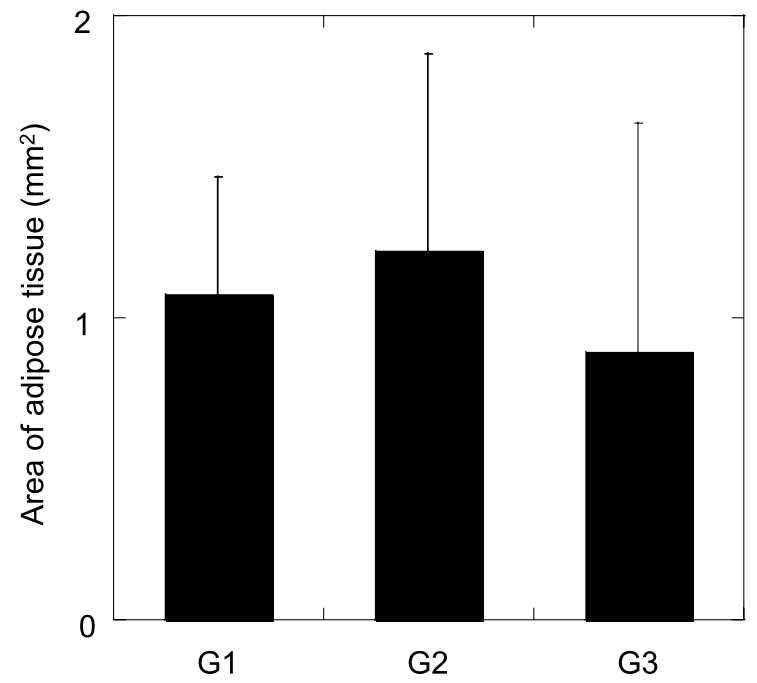

Figure 6. Area of adipose tissues newly formed 4 weeks after implantation of $\mathrm{C} 3$ collagen sponges combined with human preadipocytes, and G1, G2 and G3 gelatin microspheres incorporating bFGF into the back subcutis of nude mice.

we investigated the influence of collagen sponge biodegradability and the bFGF release profile on the adipose tissue regeneration.

In the field of tissue engineering, many biomaterials have been used as a matrix for cells scaffolds and bioactive molecules [30, 31]. The controlled release of bioactive molecules is a key factor for the successful tissue regeneration [23, 32]. For the scaffold, many researches aim at the control of physical property [33, 34], physical stiffness [35, 36] and in vivo biodegradation [36-39] to modify the cells' behavior. Among them, the scaffold degradation was studied in the area of bone substitute to achieve the proper contact with native bone tissue and prevent bone absorption around the materials implanted. In the reports, it is concluded that the faster degradation is preferred to bone tissue formation and the migration of vascular endothelial cells. However, the effect of scaffold biodegradation on the soft tissue regeneration is not investigated.

In this study, too fast and too slow degradation of collagen scaffolds resulted in less formation of adipose tissues. We have reported in the previous paper that 4 weeks needed for the in vivo formation of adipose tissue [22] and the adipose tissue formed was histologically retained until 6 weeks after implantation. We believe that evaluation 4 weeks after the implantation suffices to evaluate the effect of the time period of bFGF release and the biodegradability of collagen sponges on the in vivo formation of adipose tissues.

In Fig. 2, no difference in the cell compatibility among the collagen sponges C1C5 under serum-containing cell-culture medium condition was observed. After the GA cross-linking reaction of collagen sponges, the residual aldehyde groups of GA were chemically blocked by the treatment of sponges with excess molar of glycine. 
Therefore, we believe that the GA concentration did not affect the cell attachment. Some researches indicated that materials cross-linked with GA do not show any toxic effects to cells even without any blocking reaction [40]. Based on this, we could estimate the effect of sponge biodegradability alone on the adipose tissue engineering.

The phenomenon that less regeneration was observed in fast degraded sponges may be due the scaffolds property to make a space for tissue regeneration. The scaffold plays two important roles in tissue regeneration. One is that it provides a platform for cells to attach to and maintain life, and the other is providing space for tissue regeneration. The latter has been clinically confirmed through the guided tissue regeneration (GTR) application to dental surgery. The GTR membrane made from non-biodegradable material was used for space-making and was effective for prevention of scar tissue in-growth [41]. The fast degradation of scaffold could not provide the space for growth and differentiation of preadipocytes.

On the other hand, the phenomenon that the slow degradation of collagen sponges contributed to less adipose tissue regeneration may be due to physical impairment of the tissue-regeneration process. The collagen sponge implanted is basically not biologically natural, but foreign and artificial material, although it has been reported to function as a scaffold suitable for the initial step of regeneration. It is conceivable that the remaining in the site to be regenerated physically impairs the natural process of tissue regeneration, resulting in less new formation of adipose tissues. The balance of scaffold degradation is a key factor to induce cell-based tissue regeneration.

There was no significant effect of bFGF release profiles after 1, 3 and 5 weeks on the adipose tissue regeneration. We have demonstrated that gelatin microspheres incorporating bFGF were effective in inducing de novo adipogenesis [15]. Implantation of collagen sponges combined with human preadipocytes and gelatin microspheres for the controlled release of bFGF achieved significantly high amounts of adipose tissue newly formed compared with the solution injection of bFGF at a 10-times higher dose. Upon implanting with the collagen sponge incorporating either gelatin microspheres incorporating bFGF or human preadipocytes, and the mixture of human preadipocytes and gelatin microspheres incorporating bFGF, any particular change of tissue appearance was not observed at the implanted site. This result indicated that every combination of two of three components, collagen sponges, human preadipocytes and gelatin microspheres incorporating bFGF, did not result in formation of adipose tissue [15]. Therefore, the combination of collagen sponge, human preadipocytes and bFGF was indispensable for adipose tissue regeneration, and the local environment which allows human preadipocytes to proliferate and differentiate into matured adipocytes was provided by implantation of the collagen sponge together with the release system of bFGF. bFGF is known as a promoting factor of preadipocyte growth $[16,42]$, but its ability to induce adipogenic differentiation of preadipocytes and other cells is controversial [43-45]. On the other hand, bFGF has a strong angiogenic activity in vivo [17, 19]. In this 
study, it is possible that bFGF released acts on the initial step of de novo adipogenesis. The bFGF would induce angiogenesis and the proliferation of preadipocytes implanted. As result, no significant difference in the adipose tissue regeneration would be observed by prolonged bFGF release.

The present study clearly indicates importance of material design to achieve the optimal regeneration of adipose tissues. As expected, the in vivo biodegradability of scaffolds greatly affected the regeneration, because the existence of cell local environment undoubtedly modifies the cell behavior. In addition to the scaffold biodegradability, the chemical composition and the combination of signaling molecules must be important. This issue is presently under investigation in our laboratory.

\section{References}

1. E. Billings Jr. and J. W. May Jr., Plast. Reconstr. Surg. 83, 368 (1989).

2. R. Ellenbogen, Ann. Plast. Surg. 16, 179 (1986).

3. R. A. Ersek, Plast. Reconstr. Surg. 87, 219 (1991).

4. D. Fagrell, S. Enestrom, A. Berggren and B. Kniola, Plast. Reconstr. Surg. 98, 90 (1996).

5. J. Smahel, Br. J. Plast. Surg. 42, 207 (1989).

6. R. Langer, Tissue Eng. 13, 1 (2007).

7. Y. Tabata, Drug Discov. Today 10, 1639 (2005).

8. H. Green and O. Kehinde, J. Cell. Physiol. 101, 169 (1979).

9. E. M. Brey and C. W. Patrick, Jr., IEEE Eng. Med. Biol. Mag. 19, 122 (2000).

10. C. W. Patrick, Jr., Semin. Surg. Oncol. 19, 302 (2000).

11. D. von Heimburg, S. Zachariah, I. Heschel, H. Kuhling, H. Schoof, B. Hafemann and N. Pallua, Biomaterials 22, 429 (2001).

12. P. A. Zuk, M. Zhu, P. Ashjian, D. A. De Ugarte, J. I. Huang, H. Mizuno, Z. C. Alfonso, J. K. Fraser, P. Benhaim and M. H. Hedrick, Mol. Biol. Cell 13, 4279 (2002).

13. C. W. Patrick, Jr., P. B. Chauvin, J. Hobley and G. P. Reece, Tissue Eng. 5, 139 (1999).

14. D. von Heimburg, S. Zachariah, A. Low and N. Pallua, Plast. Reconstr. Surg. 108, 411 (2001).

15. Y. Kimura, M. Ozeki, T. Inamoto and Y. Tabata, Biomaterials 24, 2513 (2003).

16. N. Kawaguchi, K. Toriyama, E. Nicodemou-Lena, K. Inou, S. Torii and Y. Kitagawa, Proc. Natl. Acad. Sci. USA 95, 1062 (1998).

17. A. Passaniti, R. M. Taylor, R. Pili, Y. Guo, P. V. Long, J. A. Haney, R. R. Pauly, D. S. Grant and G. R. Martin, Lab. Invest. 67, 519 (1992).

18. Y. Ikada and Y. Tabata, Adv. Drug Deliv. Rev. 31, 287 (1998).

19. Y. Tabata, S. Hijikata and Y. Ikada, J. Control. Rel. 31, 189 (1994).

20. Y. Kimura, M. Ozeki, T. Inamoto and Y. Tabata, Tissue Eng. 8, 603 (2002).

21. Y. Tabata, M. Miyao, T. Inamoto, T. Ishii, Y. Hirano, Y. Yamaoki and Y. Ikada, Tissue Eng. 6, 279 (2000).

22. Y. Hiraoka, H. Yamashiro, K. Yasuda, Y. Kimura, T. Inamoto and Y. Tabata, Tissue Eng. 12, 1475 (2006).

23. M. P. Lutolf and J. A. Hubbell, Nature Biotechnol. 23, 47 (2005).

24. R. Langer and J. P. Vacanti, Science 260, 920 (1993).

25. Y. Tabata, S. Hijikata, M. Muniruzzaman and Y. Ikada, J. Biomater. Sci. Polymer Edn 10, 79 (1999). 
26. Y. Tabata and Y. Ikada, Biomaterials 20, 2169 (1999).

27. M. Ozeki and Y. Tabata, J. Biomater. Sci. Polymer Edn 16, 549 (2005).

28. K. Yasuda, S. Inoue and Y. Tabata, Tissue Eng. 10, 1587 (2004).

29. J. Rao and W. R. Otto, Anal. Biochem. 207, 186 (1992).

30. J. K. Tessmar and A. M. Göpferich, Adv. Drug Deliv. Rev. 59, 274 (2007).

31. S. Yang, K. F. Leong, Z. Du and C. K. Chu, Tissue Eng. 7, 679 (2001).

32. T. Matsumoto and D. J. Mooney, Adv. Biochem. Eng. Biotechnol. 102, 113 (2006).

33. F. J. O'Brien, B. A. Harley, I. V. Yannas and L. Gibson, Biomaterials 25, 1077 (2004).

34. V. Karageorgiou and D. Kaplan, Biomaterials 26, 5474 (2005).

35. A. J. Engler, S. Sen, H. L. Sweeney and D. E. Discher, Cell 126, 677 (2006).

36. L. Urech, A. G. Bittermann, J. A. Hubbell and H. Hall, Biomaterials 26, 1369 (2005).

37. E. Alsberg, H. J. Kong, Y. Hirano, M. K. Smith, A. Albeiruti and D. J. Mooney, J. Dent. Res. 82, 903 (2003).

38. D. P. Byrne, D. Lacroix, J. A. Planell, D. J. Kelly and P. J. Prendergast, Biomaterials 28, 5544 (2007).

39. E. Milella, E. Brescia, C. Massaro, P. A. Ramires, M. R. Miglietta, V. Fiori and P. Aversa, Biomaterials 23, 1053 (2002).

40. P. A. Ramires and E. Milella, J. Mater. Sci. Mater. Med. 13, 119 (2002).

41. H. L. Wang, H. Greenwell, J. Fiorellini, W. Giannobile, S. Offenbacher, L. Salkin, C. Townsend, P. Sheridan and R. J. Genco, J. Periodontol. 76, 1601 (2005).

42. T. E. Broad and R. G. Ham, Eur. J. Biochem. 135, 33 (1983).

43. R. M. Locklin, R. O. Oreffo and J. T. Triffitt, Cell Biol. Int. 23, 185 (1999).

44. M. Neubauer, C. Fischbach, P. Bauer-Kreisel, E. Lieb, M. Hacker, J. Tessmar, M. B. Schulz, A. Goepferich and T. Blunk, FEBS Lett. 577, 277 (2004).

45. D. A. Roncari and P. E. Le Blanc, Biochem. Cell Biol. 68, 238 (1990). 
Copyright of Journal of Biomaterials Science -- Polymer Edition is the property of VSP International Science Publishers and its content may not be copied or emailed to multiple sites or posted to a listserv without the copyright holder's express written permission. However, users may print, download, or email articles for individual use. 